\title{
The diaptomid fauna of Israel (Copepoda, Calanoida, Diaptomidae), with notes on the systematics of Arctodiaptomus similis (Baird, 1859) and Arctodiaptomus irregularis Dimentman \& Por, 1985 stat. rev
}

\author{
Federico Marrone $^{1 *}$, Adam Petrusek ${ }^{2}$, Giuseppe Alfonso ${ }^{3}$ and Marco Arculeo ${ }^{1}$
}

\begin{abstract}
Background: To date, only scarce information is available about the diaptomid copepods of the Middle East despite the ecological and biogeographical importance of the family Diaptomidae in the inland waters of the Holarctic region. Moreover, the taxonomic status of some of the taxa occurring in the area is in need of revision. We studied crustaceans collected from temporary and permanent lentic water bodies in Israel with the aim of providing an updated census of the diaptomid copepods occurring in the country. Furthermore, we morphologically and genetically analysed samples of Arctodiaptomus similis s.l. to shed light on its taxonomy.
\end{abstract}

Results: Five diaptomid taxa were collected during this survey. Among these, Phyllodiaptomus blanci is new for the country and the whole circum-Mediterranean area and might be an allochthonous species of eastern origin. Within the collected samples, we singled out two parapatric groups of populations within A. similis s.l.; these consistently differ both based on morphology (chaetotaxy of the left male antennule) and molecular data (divergence over 17\% at the mitochondrial gene for the cytochrome b). We thus attribute the full species rank to Arctodiaptomus irregularis Dimentman \& Por, 1985 stat. rev., originally described as a subspecies of the widespread species Arctodiaptomus similis (Baird, 1859).

Conclusions: We critically evaluated all species hitherto reported for Israeli inland waters. Considering both the confirmed literature data and the new findings, Israeli diaptomid fauna is composed of at least seven species. However, the need for further surveys in the Middle East and for detailed systematic revisions of some controversial taxa is stressed. Our results on the systematics of A. similis s.l. illustrate the importance of implementing molecular analyses when investigating diversity patterns of groups which are difficult to resolve based on morphology alone.

Keywords: Copepod diversity; Middle East; Hemidiaptomus gurneyi canaanita; Arctodiaptomus similis; Arctodiaptomus irregularis stat. rev; Phyllodiaptomus blanci; Neolovenula alluaudi

\footnotetext{
* Correspondence: federico.marrone@unipa.it

'Dipartimento STEBICEF, Sezione di Biologia animale ed Antropologia biologica, Universit degli Studi di Palermo, via Archirafi 18, 90123 Palermo, Italy

Full list of author information is available at the end of the article
} 


\section{Background}

Representatives of the copepod family Diaptomidae often dominate the lentic inland water bodies of the Holarctic, Oriental, and Afrotropical biogeographical regions, being a key taxon in many lacustrine and pond ecosystems (Dussart and Defaye 2001, 2002). Species of this family are as a rule characterised by limited distributional ranges, which are significantly constrained by the legacies of historical biogeographical events (Leibold et al. 2010). However, an ever-increasing corpus of molecular evidence suggests that our knowledge on diaptomid species distributions and biogeography is currently hampered by a gross underestimation of the actual diversity of the group (e.g., Marrone et al. 2013, and references therein). In the inland waters of the Mediterranean area, about 100 diaptomid species belonging to 14 genera are currently reported to occur (Dussart and Defaye 2002), but the information available for certain regions is far from being satisfactory (cf. Marrone 2006).

To date, uneven information is available on the inland water calanoid copepod fauna of the Middle East. While the diaptomid faunas of Turkey (e.g., Gndz 1998; Ustaoğlu 2004; Ustaoğlu et al. 2005) and Iran (e.g., Brehm 1937; Lffler 1956, 1961) are relatively well-known, only scarce and anecdotal records are currently available for other countries of this region (e.g., Gurney 1921; Spandl 1923; Kiefer 1978b; Dumont 1979, 2009; Khalaf 2008; Mohamed and Salman 2009). The Israeli diaptomid fauna is quite a peculiar case: although several papers and reviews are available (e.g., Baird 1859; Richard 1893; Kiefer 1930; Yaron 1964; Dimentman and Por 1985, Azoulay 2001, and references therein), only five diaptomid taxa are currently listed for the country; this seems quite a species-poor fauna when compared to other circumMediterranean regions of comparable area, where usually about 9 to 14 diaptomid species are present (e.g., Ruffo and Stoch 2005; Marrone et al. 2005; Marrone 2006; Turki and Turki 2010; Alfonso and Belmonte 2011). Furthermore, the taxonomical validity of some forms or subspecies described in the past decades based on Israeli specimens is rather controversial, and the presence itself of some taxa in the country is in need of confirmation, thus casting further uncertainty on the actual composition of the Israeli diaptomid fauna.

We studied plankton samples collected in Israeli inland waters between 2003 and 2011 in order to update the available information on the composition and distribution of diaptomid copepods in the country. Furthermore, we genetically analysed several populations of Arctodiaptomus similis s.l. to test the hypothesis that two parapatric groups of populations differing in morphology, observed in our dataset, actually represent distinct evolutionary lineages of species rank.

\section{Methods}

Plankton samples were collected throughout the country, focusing on small- to medium-sized freshwater habitats; both permanent and temporary water bodies were investigated, and some sites were sampled multiple times on different dates. Altogether, we analysed samples from 60 different sites (Figure 1). Samples were collected using a $200-\mu \mathrm{m}$ mesh hand net along the water bodies' shorelines; open waters were sampled using 80-to-200- $\mu \mathrm{m}$ meshsized towing nets. Collected crustaceans were fixed in situ with $96 \%$ ethanol. They were then sorted in the laboratory

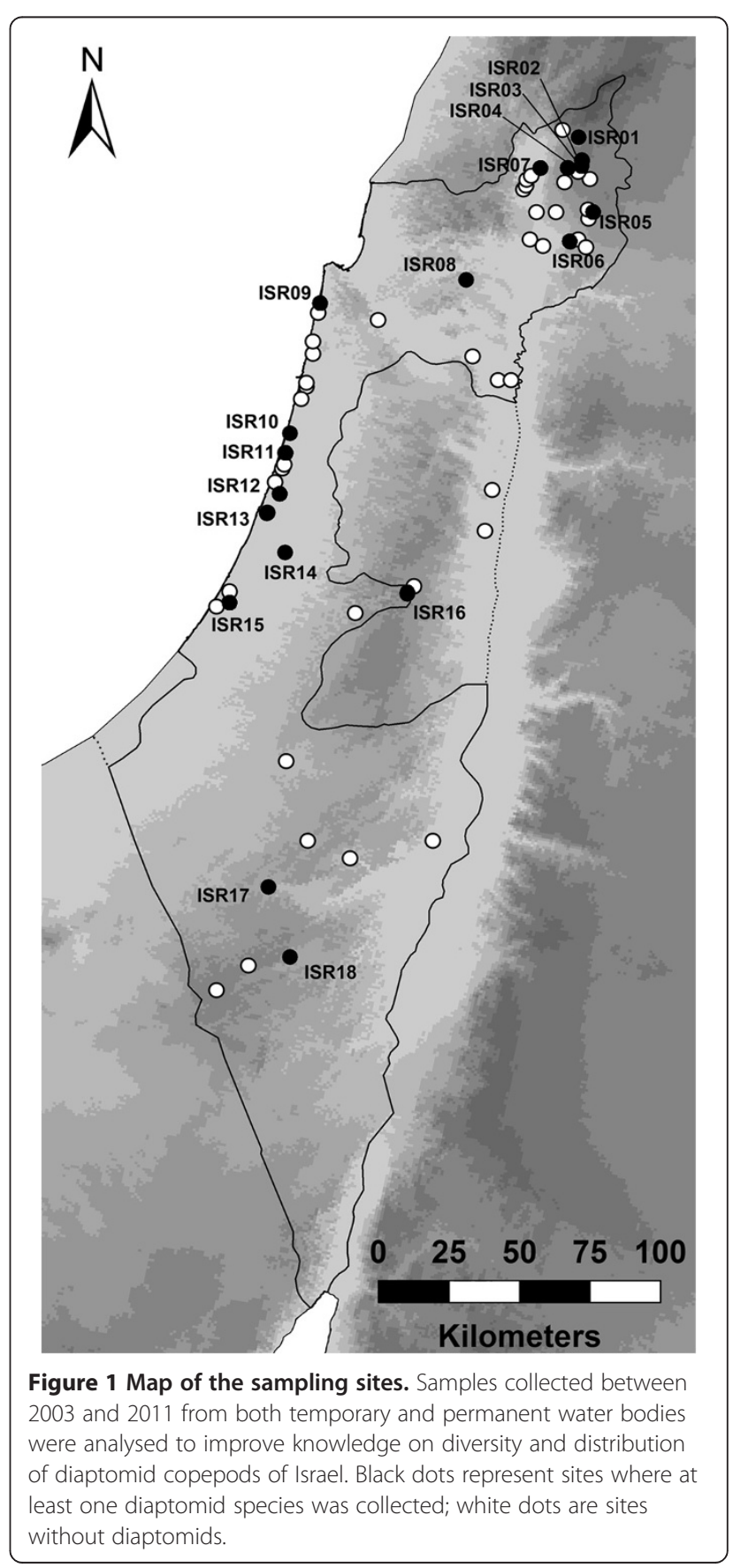


under a dissecting microscope, and diaptomid specimens were prepared according to Dussart and Defaye (2001). Morphological identification was performed according to Kiefer (1974, 1978a), Borutzky et al. (1991), and Ranga-Reddy (1994). Line drawings were prepared using a compound microscope equipped with a camera lucida.

Samples are stored in the crustacean collection of Federico Marrone and are available for loan on request. Voucher specimens from the type localities of Arctodiaptomus similis (Baird, 1859) and Arctodiaptomus irregularis Dimentman \& Por, 1985 stat. rev. have been deposited in the collection of the Smithsonian Institution (National Museum of Natural History) in Washington DC, USA, with the catalogue numbers USNM \#1226919 and USNM \#1226920.

Thirteen specimens of $A$. similis s.l. from various regions of Israel and two congeneric species to be used as outgroups (Arctodiaptomus cf. stephanidesi (Pesta, 1935) and Arctodiaptomus alpinus (Imhof, 1885), both collected in Italy) were analysed genetically by amplifying and sequencing a 329-bp long fragment of the mitochondrial gene for the cytochrome b (Cyt-b), a molecular marker which is known to be informative on the phylogeography and the molecular systematics of closely related diaptomid taxa (e.g., Staton et al. 2003; Thum and Derry 2008; Thum and Harrison 2009; Marrone et al. 2010, 2013). Genetic analyses were performed following the protocols and procedures described in Marrone et al. (2010, 2013), with the aim of investigating the molecular structuring of the taxon and to compare it with the observed patterns of morphological variation. Chromatograms were imported and edited with Chromas Lite 2.01 (Technelysium Pty. Ltd., South Brisbane, Australia) and aligned with BioEdit (Ibis Biosciences, Carlsbad, CA, USA) (Hall 1999). The quality of the obtained sequences was checked with Sequence Scanner v1.0. Only sequences with continuous reads of high quality bases were used; when the sequences were not of sufficient quality, the reverse complement sequences were also obtained. MEGA 5 (Tamura et al. 2011) was used to translate the Cyt-b sequences to amino acids in order to check for the possible presence of frameshifts or stop codons, which would indicate the presence of sequencing errors or pseudogenes. The sequences were deposited in GenBank under Accession Numbers KM488608 to KM488622.

Bayesian inference (BI) of phylogeny and maximum likelihood (ML) analyses were performed on the Cyt-b dataset as implemented by MrBayes 3.2.1 (Ronquist et al. 2012) and PhyMl v.3 (Guindon and Gascuel 2003), respectively. Both analyses were performed using a Hasegawa, Kishino, and Yano model of sequence evolution for molecular data with a proportion of invariable sites $(\mathrm{HKY}+\mathrm{I})$, as selected by the Akaike information criterion in MrModeltest 2.2 (Nylander 2004). Node supports were evaluated by their posterior probabilities in the BI tree and with 1,000 bootstrap replicates in the ML analysis. The BI analysis was performed with two independent runs of 2,000,000 generations and four Markov chains using default heating values. Trees and parameter values were sampled every 100 generations resulting in 20,000 saved trees per analysis. An initial fraction of 5,000 trees (20\%) was conservatively discarded as burn-in. For all analyses, standard deviation of split frequencies reached values lower than 0.0065 , and values of the potential scale reduction factor (PSRF) were between 1.0 and 1.004 for all parameters, indicating convergence of the runs.

In order to compare the observed molecular distances with those available in literature for other diaptomid taxa, uncorrected molecular distances among specimens and between groups were calculated in PAUP 4.0b10 (Swofford 1998).

\section{Results}

\section{Morphological identification}

We analysed samples originating from 60 different sampling sites. In 18 sites, diaptomid copepods were present (Figure 1, Table 1). Most of these habitats were temporary rain pools; diaptomids were only rarely encountered in permanent water bodies such as reservoirs and fishponds, although these were well-represented in our sample set. Altogether, five diaptomid taxa were collected (Table 2). Among these, Hemidiaptomus gurneyi canaanita, two forms of A. similis s.l., and Neolovenula alluaudi were already known for the fauna of the country. Conversely, the finding of Phyllodiaptomus blanci in a reservoir of a city park in Tel Aviv is the first one for Israel and for the whole circum-Mediterranean area. In spite of previously published findings, no Eudiaptomus species were collected during the present survey.

Studied A. similis s.l. populations differed in the antennular chaetotaxy, which consistently presents one versus two setae on the 15th and 17th segments of the left male antennule (Figure 2). Based on this character, these could be ascribed to two parapatric groups, one restricted to water bodies of the Golan Heights only, the other found in other regions of the country (Table 3).

\section{Molecular analyses}

The BI and ML trees based on a 329-bp long fragment of the Cyt-b showed a concordant topology, with a clear division of the investigated $A$. similis s.l. samples into two groups, hereafter referred to as the Golan and the Israeli clades (Figure 3). These clades are in good accordance with the two groups singled out based on morphology (Table 3) and show a sharp geographical segregation.

The mean intra-clade uncorrected molecular distance was $1.6 \%$ (ranging from $0.9 \%$ to $3 \%$ ) within the Israeli 
Table 1 List of the sampled localities with diaptomid presence

\begin{tabular}{llllll}
\hline Code & Site name - district & Sampling date(s) & Latitude (N) & Longitude (E) & Hydroperiod \\
\hline ISR01 & Lake Ram - Golan Heights & 14 March 2011 & 33.23639 & 35.76583 & Permanent \\
ISR02 & Pool at El Rom - Golan Heights & 9 March 2010 & 33.16472 & 35.77694 & Temporary \\
ISR03 & Bab El Hawa pool - Golan Heights & 9 March 2010 & 33.14333 & 35.77417 & Temporary \\
ISR04 & Orvim reservoir - Golan Heights & 7 March 2010; 14 March 2011 & 33.13972 & 35.73194 & Permanent \\
ISR05 & Khusniya pool - Golan Heights & 8 March 2010 & 32.99583 & 35.81056 & Temporary \\
ISR06 & Vernal pools close to Daliyot Reservoir, Golan Heights & 8 February 2003 & 32.89972 & 35.77589 & Temporary \\
ISR07 & Lehavot Habashan - Northern District & 15 March 2011 & 33.13833 & 35.64389 & Permanent \\
ISR08 & Mashkena pool - Northern District & 6 March 2010; 17 March 20111 & 32.78111 & 35.4075 & Temporary \\
ISR09 & Ditch at Atlit - Haifa District & 30 January 2003 & 32.70444 & 34.94194 & Temporary \\
ISR10 & Dora pool - Haifa District & 7 March 2011 & 32.29111 & 34.84583 & Temporary \\
ISR11 & Ga'ash pool - Haifa District & 7 March 2011 & 32.22889 & 34.83083 & Temporary \\
ISR12 & Pond in Yarkon park - Tel Aviv District & 29 January 2003 & 32.09722 & 34.81278 & Permanent \\
ISR13 & Pond in Holon - Tel Aviv District & 26 January 2004 & 32.03472 & 34.77194 & Temporary \\
ISR14 & Moshav Ishrash - Center District & Not available. & ca 31.90 & ca 34.83 & Temporary \\
ISR15 & Rainwater-flooded field near Tel Ashdod - Southern District & 22 January 2004 & 31.75167 & 34.65194 & Temporary \\
ISR16 & Mamilla pool - Jerusalem District & 4 March 2011 & 31.77801 & 35.22058 & Temporary \\
ISR17 & Small pools in Sde Boker, Vadi Zin - Southern District & 9 March 2011 & 30.84167 & 34.77722 & Temporary \\
ISR18 & Pool in Makhtesh Ramon crater - Southern District & 12 March 2010; 17 March 2011 & 30.61694 & 34.84611 & Temporary \\
\hline
\end{tabular}

Decimal geographical coordinates (WGS84) are provided.

clade and $0.7 \%$ (ranging from $0 \%$ to $0.9 \%$ ) within the Golan clade. The average uncorrected molecular distance between the two clades was $17.3 \%$.

\section{Discussion}

\section{Checklist and distribution}

Five diaptomid taxa were collected in the present survey; in addition to these, Eudiaptomus drieschi and Arctodiaptomus (Rhabdodiaptomus) salinus have to be considered parts of the Israeli diaptomid checklist based on bibliographical evidence. The reports of Arctodiaptomus (Arctodiaptomus) wierzejskii and Eudiaptomus gracilis in the country are in need of being substantiated and are possibly erroneous (see comments below). At the present state of knowledge, the checklist of Israeli diaptomid copepods is thus composed of seven taxa (Table 2).

The paradiaptomid $N$. alluaudi, which was previously known in the country only from the Sinai and Negev deserts (Dimentman and Por 1985), was collected in our survey both in the Negev desert and on the Golan Heights, thus widening to the north the distribution of this species in the country. This finding was recently anticipated by Alfonso and Belmonte (2013) in a review on N. alluaudi distribution.

\section{Table 2 Checklist of Israeli Diaptomidae (Copepoda, Calanoida)}

\begin{tabular}{|c|c|c|}
\hline Taxa & Sites of occurrence (present study) & Sources \\
\hline \multicolumn{3}{|l|}{ Diaptominae } \\
\hline $\begin{array}{l}\text { Hemidiaptomus (Hemidiaptomus) gurneyi canaanita } \\
\text { Dimentman \& Por, } 1985\end{array}$ & ISR02, ISR05, ISR06, ISR11, ISR14 & $2,6,8,9,11,13$ \\
\hline${ }^{a} E$ udiaptomus drieschi (Poppe \& Mrzek 1895) & n.d. & 10 \\
\hline Arctodiaptomus (Arctodiaptomus) similis (Baird, 1859) & ISR07, ISR08, ISR09, ISR10, ISR11, ISR13, ISR15, ISR16 & \multirow{2}{*}{$1,2,3,4,5,6,7,8,9,10,13$} \\
\hline Arctodiaptomus (Arctodiaptomus) irregularis Dimentman \& Por, 1985 & ISR02, ISR03, ISR04, ISR05, ISR06 & \\
\hline${ }^{a}$ Arctodiaptomus (Rhabdodiaptomus) salinus (Daday, 1885) & n.d. & 2 \\
\hline${ }^{b}$ Phyllodiaptomus blanci (Guerne \& Richard, 1896) & ISR12 & 13 \\
\hline \multicolumn{3}{|l|}{ Paradiaptominae } \\
\hline Neolovenula alluaudi (Guerne \& Richard, 1890) & ISR01, ISR03, ISR17, ISR18 & $8,9,12,13$ \\
\hline
\end{tabular}

${ }^{a}$ Not found during the present survey; ${ }^{b}$ first record for Israel. The actual occurrence of Arctodiaptomus wierzejskii and Eudiaptomus gracilis in Israel is doubtful, and the species are not included in the table (see Discussion section). The codes of sampling sites refer to Table 1. n.d., not detected. Sources: 1: Baird (1859); 2: Richard (1893); 3: Kiefer (1930); 4: Fischer (1953); 5: Petkovski (1961); 6: Yaron (1964); 7: Kiefer (1974); 8: Por (1984); 9: Dimentman \& Por (1985); 10: Azoulay (2001); 11: Marrone et al. (2010); 12: Alfonso \& Belmonte (2013); 13: Present work. 


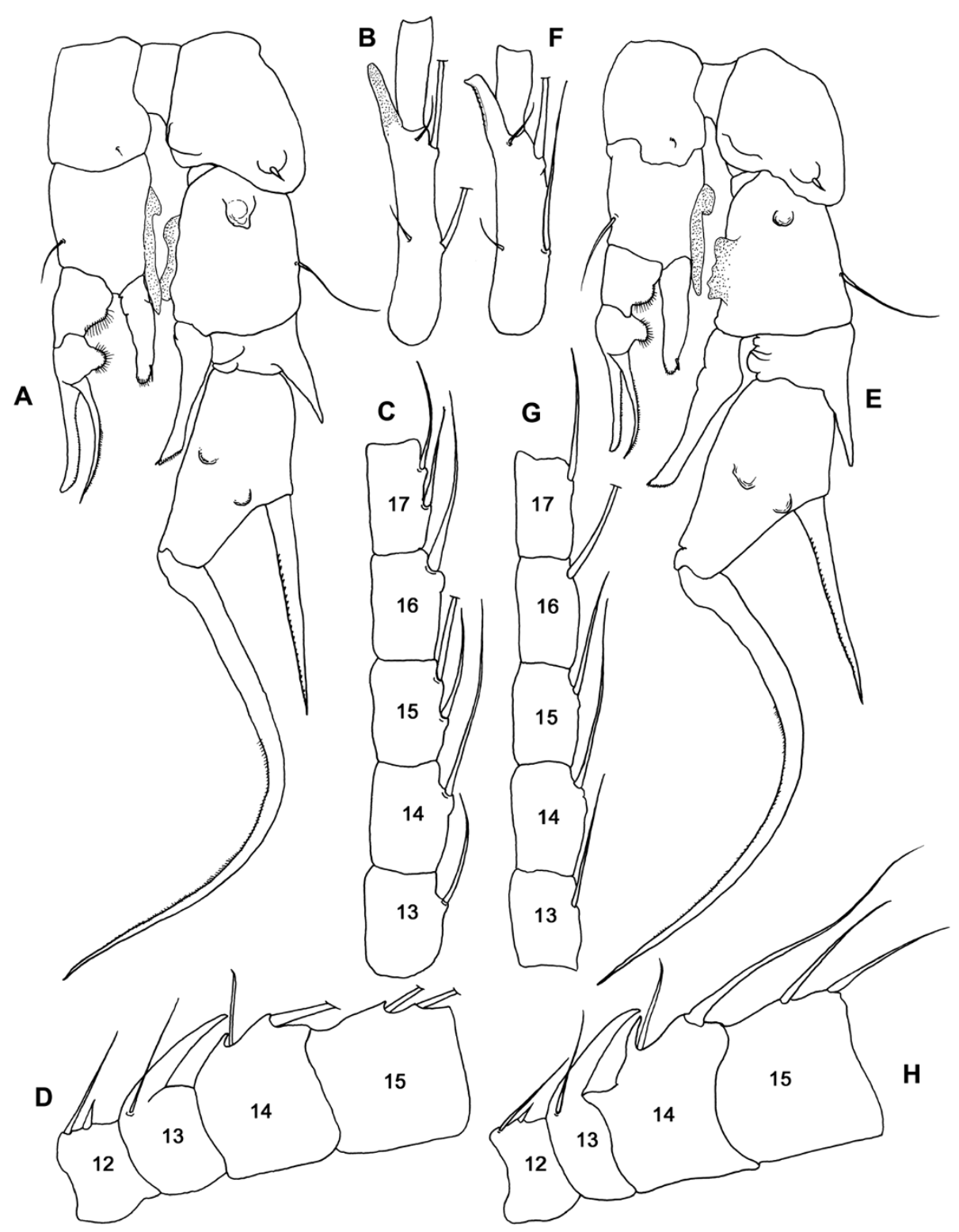

Figure 2 Arctodiaptomus similis (Baird, 1859) and Arctodiaptomus irregularis Dimentman \& Por, 1985. Anatomical features of A. irregularis collected in Bab El Hawa (ISR03) on 9 March 2010 (A-D) and A. similis collected in Birket Mamilla pool (ISR16) on 4 March 2011 (E-H). A and E: male fifth pair of the legs (posterior view). B and $\mathbf{F}$ : antepenultimate article of the male right antennula. $\mathbf{C}$ and $\mathbf{G}$ : detail of the chaetotaxy on the articles 13 to 17 of the male left antennula. $\mathbf{D}$ and $\mathbf{H}$ : articles 12 to 15 of the male right antennula. Scale bar $100 \mu \mathrm{m}$.

Hemidiaptomus (Hemidiaptomus) gurneyi canaanita is an endemic taxon whose distinct status was confirmed by molecular analyses, in spite of the morphological identity of Israeli populations with those collected in the central Mediterranean, including the type locality of the species (Marrone et al. 2010). Hemidiaptomus gurneyi s.l. is characterised by a sharply disjointed distribution, with the populations belonging to Hemidiaptomus gurneyi gurneyi occurring in the central Mediterranean area (from eastern Algeria to the Balkan Peninsula), and those belonging to the subspecies Hemidiaptomus gurneyi canaanita occurring in Israel (Marrone et al. 2010). The report of the presence of the species in Hungary (Dussart and Defaye 2002) is not supported by any reference or sample (cf. Kiefer 1978a; Petkovski 1983; Stella 1984; Dussart 1989; Borutzky et al. 1991; Marrone et al. 2010); it has thus to be considered a lapsus calami of the authors. In our survey, $H$. gurneyi canaanita was collected in water bodies of central and northern areas of Israel, which is in good accordance with the distribution pattern described for the 
Table 3 A. similis s.l. populations based on setae number on 13th, 15th, and 17th segments of left male antennule

\begin{tabular}{|c|c|c|c|}
\hline Population & $N$ & $1-1-1$ & $1-2-2$ \\
\hline ISR01 - Golan Heights & 3 & & $\sqrt{ }$ \\
\hline ISRO2 - Golan Heights & 3 & & $\sqrt{ }$ \\
\hline ISR03 - Golan Heights ${ }^{\mathrm{a}}$ & 5 & & $\sqrt{ }$ \\
\hline ISR04 - Golan Heights & 1 & & $\sqrt{ }$ \\
\hline ISR05 - Golan Heights & 3 & & $\sqrt{ }$ \\
\hline ISR06 - Golan Heights & 5 & & $\sqrt{ }$ \\
\hline ISR07 - Northern District & 1 & $\sqrt{ }$ & \\
\hline ISR08 - Northern District & 2 & $\sqrt{ }$ & \\
\hline ISR11 - Haifa District & 1 & $\sqrt{ }$ & \\
\hline ISR13 - Tel Aviv District & 3 & $\sqrt{ }$ & \\
\hline ISR15 - Southern District & 4 & $\sqrt{ }$ & \\
\hline ISR16 - Jerusalem District ${ }^{\text {b }}$ & 6 & $\sqrt{ }$ & \\
\hline
\end{tabular}

No males were available from populations ISR09 and ISR10. N, number of male

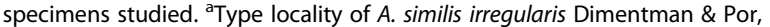

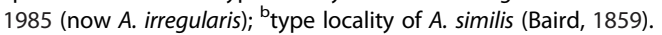

species by Dimentman and Por (1985). Based on the available drawing, the report of the occurrence of a female Hemidiaptomus specimen in Birket de Banias (Richard 1893), originally attributed to Hemidiaptomus amblyodon (Marenzeller, 1873) by the author, can in fact be unequivocally ascribed to $H$. gurneyi canaanita.

Two species belonging to the genus Eudiaptomus are to date reported for the country: Eudiaptomus gracilis (G.O. Sars, 1863) and Eudiaptomus drieschi (Poppe \& Mrzek, 1895), both of them for Lake Kinneret (see Azoulay 2001, and references therein). As it has already been stressed (e.g., Dimentman and Por 1985; Azoulay 2001), it is possible that the early reports of $E$. gracilis for Lake Kinneret should be in fact ascribed to a misidentification of $E$. drieschi, and that E. gracilis should thus be excluded from Israeli diaptomid fauna. However, conclusive evidence is not available, and the report of occurrence of this euryecious diaptomid species in the lake cannot be excluded. Eudiaptomus species were observed in Lake Kinneret only since the 1960s onwards, although the Lake Kinneret zooplankton was investigated by frequent sampling since the early 20th century. This suggests a relatively recent colonization of the lake from an unknown source area,

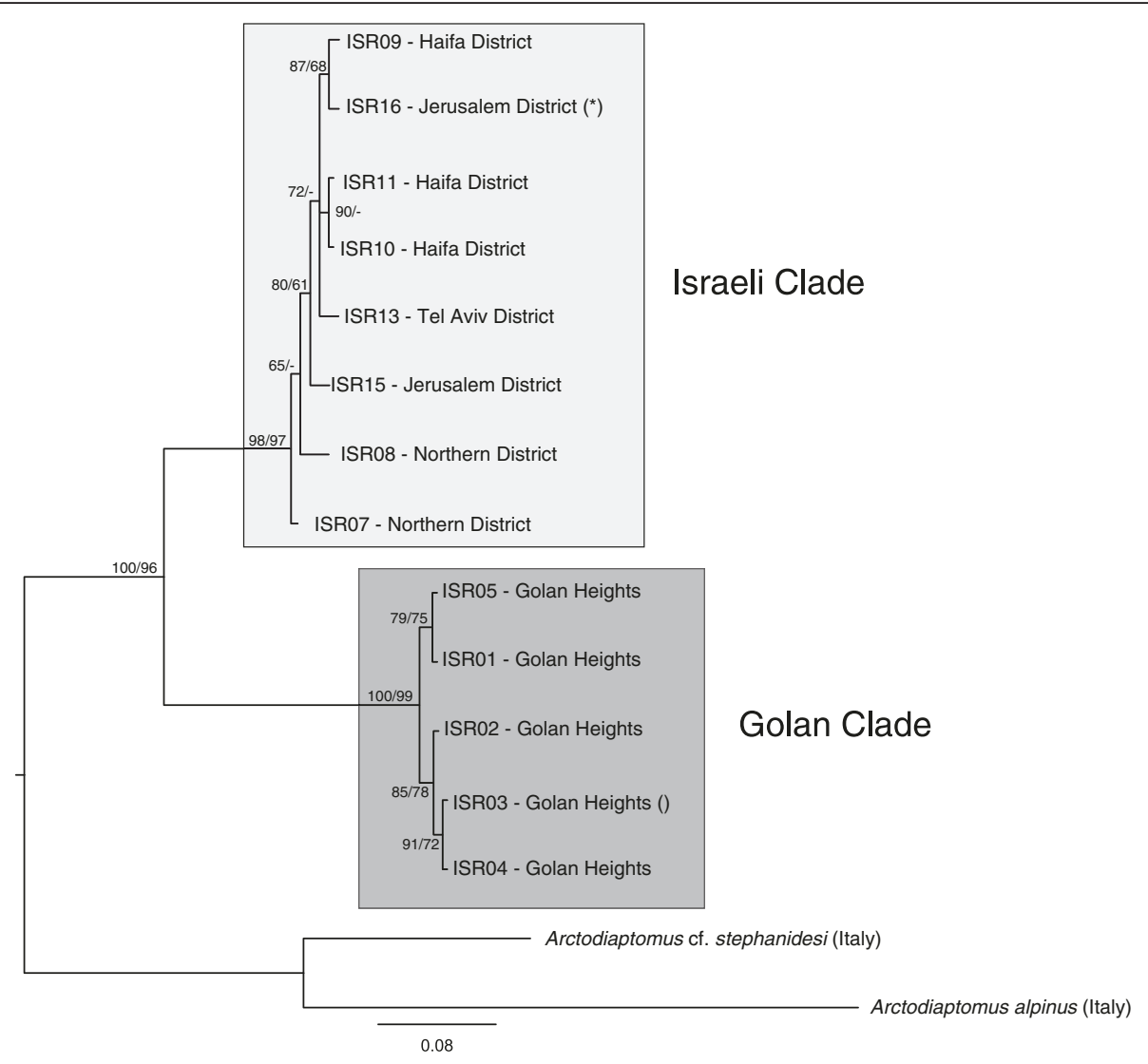

Figure 3 Bayesian phylogram based on a 329-bp long fragment of the mitochondrial gene for the cytochrome b. Node support is reported as nodal posterior probabilities/ML bootstrap; values below 50 are indicated by a dash. Asterisk (*): type locality of A. similis (Baird, 1859); Section sign (): type locality of A. similis irregularis Dimentman \& Por, 1985 (now A. irregularis). 
possibly corresponding with various anthropogenic changes of the Lake Kinneret system which took place since the 1950s, including intensive stocking of fish exotic to the lake (e.g., Gophen 1979). No Eudiaptomus species were collected during our survey; however, we did not sample this large freshwater lake.
A thriving population of the diaptomid P. blanci was observed in a permanent reservoir within a city park in Tel Aviv (Figure 4). This species is new for Israel and the whole circum-Mediterranean area. Phyllodiaptomus is a diaptomid genus whose distribution area encompasses Central and Eastern Asia, from India to Iraq (Borutzky
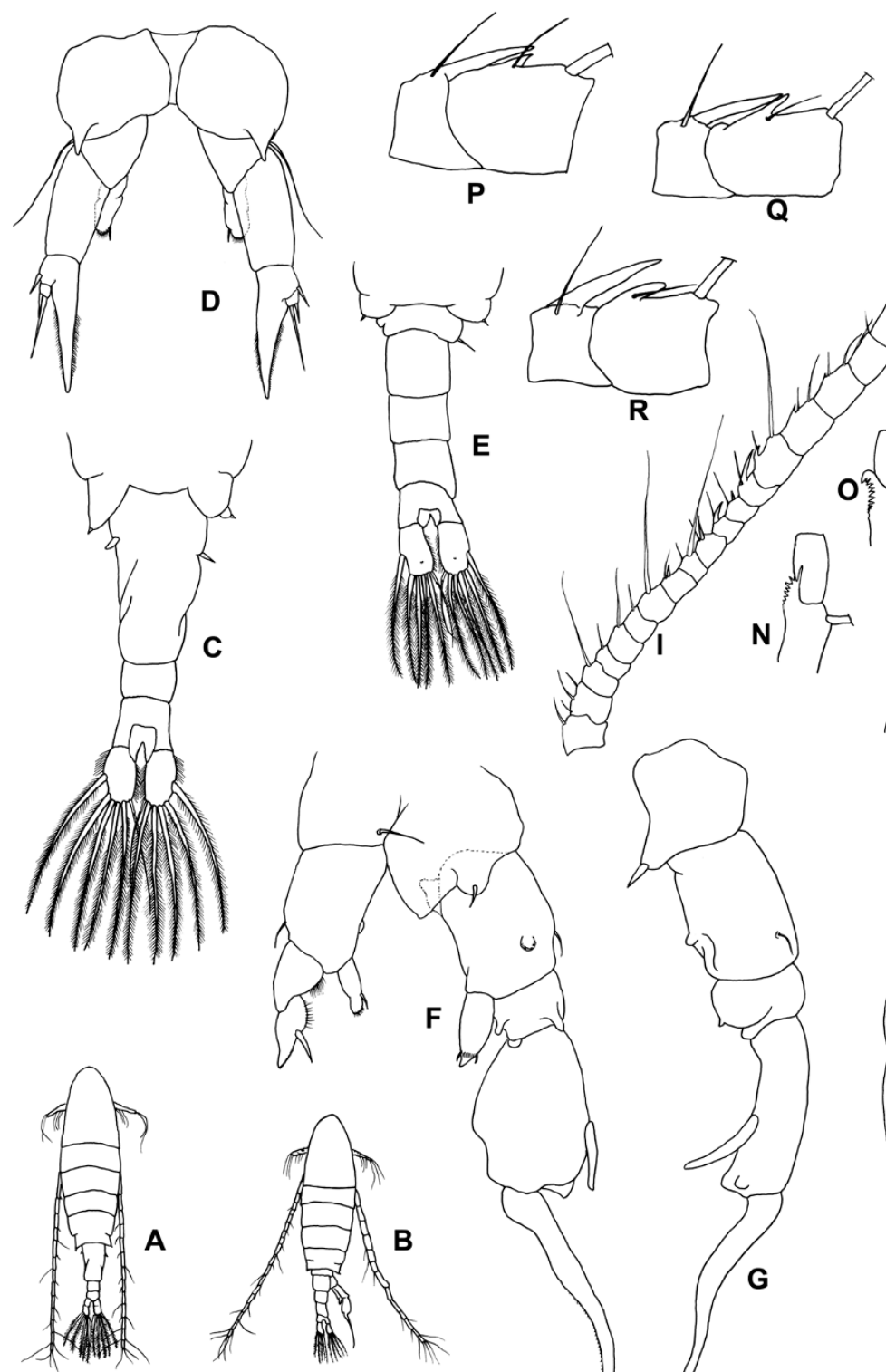

- A, B
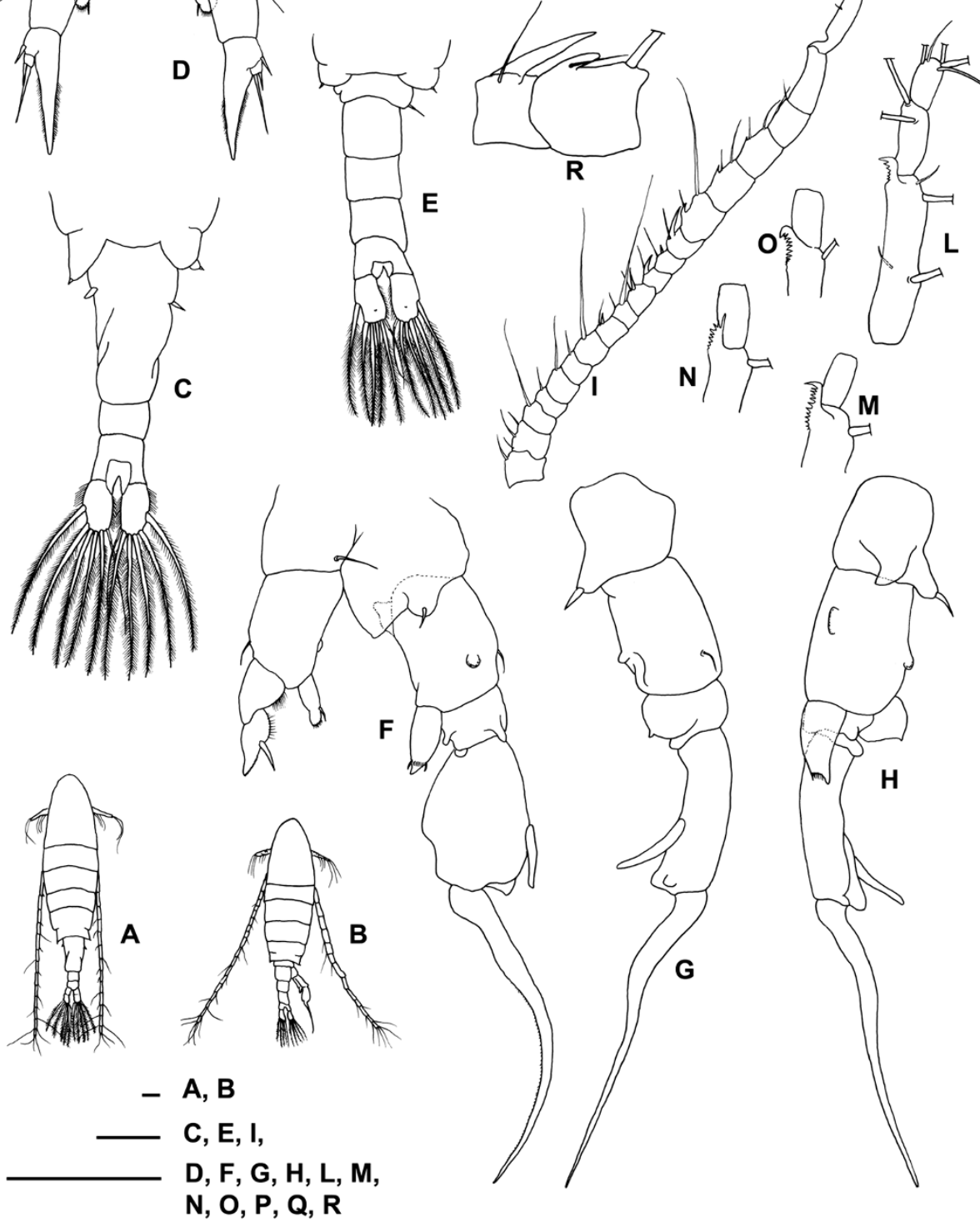

N)

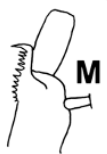

$\mathbf{F}$
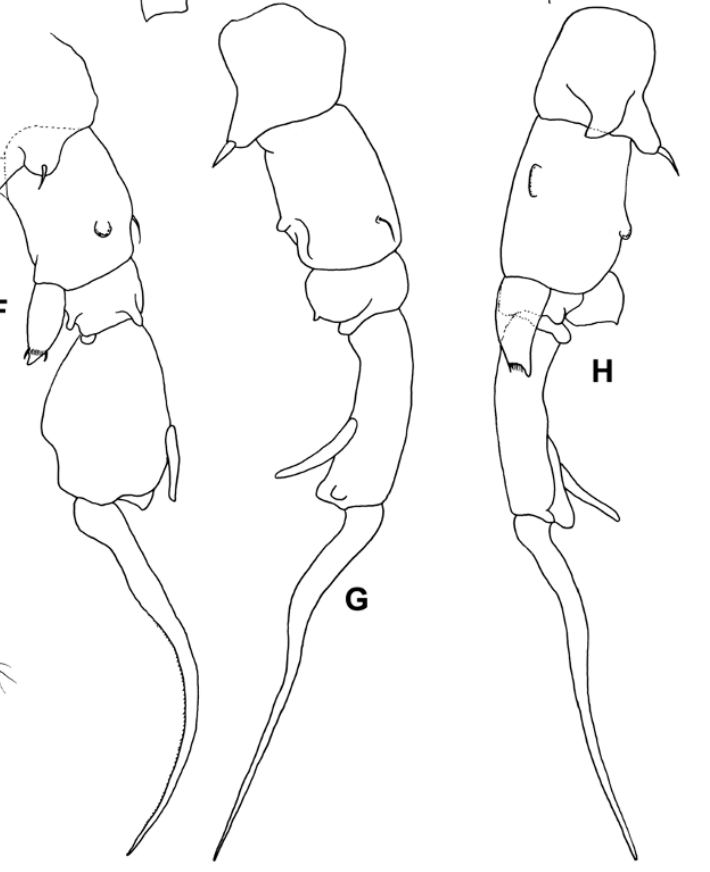

Figure 4 Phyllodiaptomus blanci. Specimens collected in Tel Aviv on 29 January 2003 (ISR12). (A) Female habitus, dorsal view. (B) Male habitus, dorsal view. (C) Female urosome, dorsal view. (D) Female fifth pair of legs, posterior view. (E) Male urosome, dorsal view. (F) Male fifth pair of legs, posterior view. (G) Male right leg, outer lateral view. (H) Male right leg, inner lateral view. (I) Male right antennula. (L-O) Variability of the antepenultimate segment of the male right antennula. (P-R) Variability of 13 and 14 articles of the male right antennula. Scale bar $100 \mu$ m. 
et al. 1991; Ranga-Reddy 1994; Sanoamuang and Teeramaethee 2006; Khalaf 2008). P. blanci and Phyllodiaptomus irakiensis are the westernmost species of the genus, both of them being known to occur in Iraq (Khalaf 2008, and references therein). It is not clear whether the presence of a $P$. blanci population in Israel is to be ascribed to an anthropogenic introduction to the country or whether the species has to be considered autochthonous. However, the man-made origin of the single known Israeli locality of this species suggests that, pending further findings in the area, P. blanci is an alien copepod species in Israel.

Richard (1893) reported the occurrence of Arctodiaptomus (Rhabdodiaptomus) salinus from Birket Abo-Zeineh, a brackish marsh close to the northern coast of Lake Kinneret. The species is considered part of the Israeli fauna by Ranga-Reddy (1994) and Dussart and Defaye (2002). Dimentman and Por (1985) considered that this finding needed to be substantiated; however the presence of $A$. salinus in Israel is rather likely as this halophilous taxon is characterised by a broad circum-Mediterranean and Palaearctic distribution, including several countries in the Middle East (Dussart and Defaye 2002; Dumont 2009). Inland endorheic water bodies and salty coastal marshes and lagoons are the habitats to be sampled in order to find new evidence for the presence of this taxon in Israel.

Arctodiaptomus (Arctodiaptomus) wierzejskii was xerroneously cited to be present in Israel by Yaron (1964), who misidentified $A$. similis s.l. for this species (this erroneous datum was then unfortunately perpetuated by Dussart and Defaye 2002). The mistake was possibly due to the use of the trinomen Diaptomus wierzejskii palaestinensis by Kiefer (1930) for the diaptomid population inhabiting Birket Mamilla and by Fischer (1953) for the populations inhabiting some fish ponds throughout the country. D. wierzejskii palaestinensis is in fact a synonym of Arctodiaptomus similis (Kiefer 1932, 1974).

The diaptomin taxon Arctodiaptomus (Arctodiaptomus) similis s.l. (Baird, 1859) inhabits both permanent and temporary water bodies of central and northern parts of the country, proving to be the commonest calanoid copepod occurring in Israeli inland waters. In spite of its abundance, the taxonomy of $A$. similis s.l. is to date controversial. Currently, two taxa of subspecific rank are ascribed to $A$. similis s.l., but the taxonomical arrangement of the species is in need of revision (cf. Ranga-Reddy 1994; Dussart and Defaye 2002). The species was described from Israel by Baird (1859) and later reported to occur throughout Southwestern Asia and Eastern Europe (e.g., Richard 1893; Petkovski 1961; Kiefer 1930, 1974, 1978; Dimentman and Por 1985, Azoulay 2001, Dussart and Defaye 2002). Some authors reported the presence of the species in Sardinia (Kiefer 1978a; Dussart and Defaye, 2002) without providing any drawing or precise locality data; furthermore, extensive limnological surveys carried out in the island (e.g., Stella 1970; Stella et al. 1972; Stella and Margaritora 1975/1976; Fadda et al. 2011; Marrone and Stoch, unpublished data) only recorded the presence of the congeneric species $A$. salinus and $A$. wierzejskii, and no evidence of the presence of $A$. similis s.l. was ever collected. Thus, the report of the presence of the species in Sardinia is almost certainly erroneous, and the species is currently not considered part of the Italian copepod fauna (Stella 1984; Ruffo and Stoch 2005). The Israeli populations of $A$. similis s.l. studied by us could be split into two parapatric groups (Table 3), differing in the chaetotaxy of the left male antennule (Figure 2C,G) and in the mtDNA Cyt-b sequences (Figure 3).

\section{Taxonomical notes on Arctodiaptomus (Arctodiaptomus) similis (Baird, 1859) and Arctodiaptomus (Arctodiaptomus) irregularis Dimentman \& Por, 1985 stat. rev}

A. similis was described by Baird (1859) based on specimens raised from dried mud collected in the pool of Gihon in Jerusalem (now Birket Mamilla pond). Later on, Kiefer (1930) described D. wierzejskii palaestinensis based on specimens collected in Birket Mamilla, but this taxon was later synonymised, by the author himself, with $A$. similis (see Kiefer 1974 for an annotated list of the synonyms of the species). In the same work, Kiefer (1974) stressed the variability of the ornamentation and chaetotaxy of the male antennule and established two infrasubspecific formae based on the presence of two versus one setae on the 13th, 15th, and 17th segments of the left male antennule (forma saetosior) and on the presence of a rodlike instead of claw-like process of the antepenultimate segment of the right male antennule (forma irregularis). Based on this last character, and on the presence versus absence of a tooth on the 14th segment of the right male second antenna, Dimentman and Por (1985) established the subspecies Arctodiaptomus similis irregularis, whose type locality lies in Birket Bab el Hawa, on the Golan Heights. However, it has to be stressed that several authors (Richard 1893; Petkovski 1961; Kiefer 1974, 1978a) reported the presence of a pronounced intra-populational morphological variability for the morphological characters which, according to Dimentman and Por (1985), should allow unequivocal assignment of each population to one or the other subspecies.

In good accordance with Richard (1893) and Petkovski (1961), the A. similis s.l. populations studied by us showed a noteworthy variability in the morphology of the right male antennule; although the populations from the Golan Heights show, as a rule, a smaller tooth on the 14th segment (Figure 2D) and a blunter process on the antepenultimate segment of the antennule (Figure 2B), exceptions and intermediate forms were observed. Conversely, the 
number of setae on the 15th and 17th segments of the left male antennule allowed us to soundly distinguish the specimens collected throughout the country in two groups (Table 3). This observation is in sharp contrast with Kiefer $(1974,1978 a)$, who stressed a significant variability for the chaetotaxy of the segments 13th, 15th, and 17th both at intra- and inter-population level.

The two groups of populations singled out based on the number of setae present on the 15th and 17th segments of the left male antennule (Figure 2C,G) are parapatric and in good accordance with the observed molecular clustering in two clades of the studied populations (Figure 3). The molecular distance observed between the two groups is of the same order of magnitude of those observed among different lineages deserving the status of cryptic species within other diaptomid species, like Skistodiaptomus pallidus (14.3\% to $17.2 \%$, Thum and Harrison 2009), Hemidiaptomus ingens (18\%, Marrone et al. 2010), and Onychodiaptomus sanguineus (22\%, Thum and Derry 2008); furthermore, a high sequence similarity was observed within each of the two clades.

Our morphological and genetic data thus support a classification of Israeli $A$. similis s.l. into two main lineages of species rank. Accordingly, two species are present in Israel: A. similis (Baird, 1859) (Figure 2E,F,G,H), inhabiting the whole country with the exception of the Golan Heights, and A. irregularis Dimentman \& Por, 1985 stat. rev. (Figure 2A,B, C,D), apparently confined to the Golan Heights.

\section{Arctodiaptomus similis (Baird, 1859)}

Type locality: Mamilla pool (Jerusalem District; ISR16) syn.: Diaptomus wierzejskii palaestinensis Kiefer, 1930 Arctodiaptomus similis similis Dimentman \& Por, 1985

\section{A. irregularis Dimentman \& Por, 1985 stat. rev.}

Type locality: Bab el Hawa pool (Golan Heights; ISR03) syn.: Arctodiaptomus similis forma irregularis Kiefer, 1974 Arctodiaptomus similis irregularis Dimentman \& Por, 1985

The two taxa Arctodiaptomus similis var. smirnovi Brehm, 1938 and Arctodiaptomus spectabilis Mann, 1940 are junior synonyms of $A$. similis s.l. (cf. Kiefer, 1974), but at the current state of knowledge, it is impossible to soundly ascribe them to, or differentiate from, either $A$. similis s.s. or $A$. irregularis. The distribution of these two taxa in the Middle East and Eastern Europe is in fact to date unknown. Interestingly, a parapatric distribution of two distinct lineages similar to that within $A$. similis has also been observed in Israeli populations of the cladoceran Daphnia (Ctenodaphnia) chevreuxi Richard, 1896: one lineage was only detected in lowland pools in the Mediterranean coastal plain, while a genetically distinct lineage was widespread in the Golan Heights but not found elsewhere (A. Petrusek, unpublished data).

\section{Conclusions}

In the light of a critical review of the existing and new data, the calanoid family Diaptomidae proved to be better represented in Israel than previous literature data suggested, with seven species certainly occurring in the country. This value is close to that observed in other circum-Mediterranean countries of comparable size (e.g., Marrone 2006). Furthermore, it also needs to be stressed that representatives of the genus Metadiaptomus, known to occur throughout the arid regions of the Mediterranean and Black Sea (e.g., Kiefer 1978b; Jaume 1989; Rayner 1999; Marrone and NaselliFlores 2005: Samchyshyna 2011, and references therein), although never recorded to date in Israel, are likely to also occur in the country; for instance, Metadiaptomus chevreuxi (de Guerne \& Richard, 1894) is known from Jordan, and Metadiaptomus mauretanicus Kiefer \& Roy, 1942 from Egypt (Dumont 1979, 2009).

Based on the updated checklist of Israeli diaptomids (Table 2), counts of endemic (i.e., H. gurneyi canaanita, A. irregularis) and eastern taxa (A. similis, E. drieschi, P. blanci) in this country are comparable to counts of taxa with wider distribution areas (i.e., Arctodiaptomus salinus and Neolovenula alluaudi). Unfortunately, due to a lack of sound checklists for most of the other Middle East countries, it is currently difficult to understand the biogeographic affinities of the Israeli calanoid copepod fauna.

The possible presence of an allochthonous species in the country is in accordance with the ever-growing number of successful biological invasions affecting the freshwater zooplankton in the last decades. Such phenomenon is becoming increasingly important in the Western Palaearctic region, where the records of allochthonous calanoid copepods are increasing at a fast pace (e.g., Ferrari et al. 1991; Rossetti et al. 1996; Alfonso and Belmonte 2008; Brandorff 2011; Alfonso et al. 2014).

\section{Competing interests}

The authors declare that they have no competing interests

\section{Authors contributions}

FM carried out the morphological identification of the samples, carried out the molecular analyses, and drafted the manuscript. AP carried out the samplings in Israel and helped to draft the manuscript. GA helped with the bibliographical research, realised the figures, and provided important comments to a first draft of the manuscript. MA supervised and coordinated the research and helped with the molecular analyses. All authors read and approved the final manuscript.

\section{Acknowledgements}

Nicolas Rabet (National Museum of Natural History, Paris, and University Pierre and Marie Curie, Paris) kindly provided the diaptomid sample from Moshav Ishrash (Center District). Tereza Petruskov helped during the sampling campaigns. T. Chad Walter (National Museum of Natural History, Washington DC) kindly provided the catalogue numbers of the copepod specimens deposited in the collection of the Smithsonian Institution. We thank Fabio Stoch (University of L'Aquila, L'Aquila) for his help in the correct 
application of the International Code of Zoological Nomenclature and Jessica Richardson for language corrections.

The research was partially supported by the Fondi di Ateneo (60\%) of the University of Palermo.

\section{Author details}

${ }^{1}$ Dipartimento STEBICEF, Sezione di Biologia animale ed Antropologia biologica, Universit degli Studi di Palermo, via Archirafi 18, 90123 Palermo, Italy. ${ }^{2}$ Department of Ecology, Faculty of Science, Charles University in Prague, Viničn 7, 12844 Prague 2, Czech Republic. ${ }^{3}$ Dipartimento di Scienze e Tecnologie Biologiche e Ambientali - Di.S.Te.B.A, Laboratorio di Zoogeografia e Fauna, Universit del Salento, via Monteroni campus Ecotekne, 73100 Lecce, Italy.

Received: 25 June 2014 Accepted: 14 November 2014 Published online: 12 December 2014

\section{References}

Alfonso G, Belmonte G (2008) Expanding distribution of Boeckella triarticulata (Thomson, 1883) (Copepoda: Calanoida: Centropagidae) in Southern Italy. Aquat Invasions 3:247 251

Alfonso G, Belmonte G (2011) Calanoida (Crustacea Copepoda) from the inland waters of Apulia (south-eastern Italy). J Limnol 70:57 68

Alfonso G, Belmonte G (2013) Neolovenula alluaudi (Guerne and Richard, 1890) (Calanoida: Diaptomidae: Paradiaptominae): first record in Italy and review of geographical distribution. J Limnol 72:251 261

Alfonso G, Russo R, Belmonte G (2014) First record of Neodiaptomus schmackeri (Poppe \& Richard, 1892) (Copepoda: Calanoida: Diaptomidae) in Europe: evidences of a successful invasion from Asia. J Limnol 73:584 592

Azoulay BR (2001) The Autoecology of Eudiaptomus cf. drieschi (Poppe \& Mrazek 1895) (Copepoda, Calanoida) in Lake Kinneret. PhD thesis. The Hebrew University of Jerusalem, Israel

Baird W (1859) Description of several species of Entomostracous Crustacea from Jerusalem. Ann Mag nat Hist (ser III) 4:280 293

Borutzky EB, Stepanova LA, Koss MS (1991) Opredelitel' Calanoida presnykh vod SSSR. Nauka, St. Petersburg

Brandorff GO (2011) The copepod invader Skistodiaptomus pallidus (Herrick, 1879) (Crustacea, Copepoda, Diaptomidae) from North America in water bodies of Bremen, northern Germany. Aquat Invasions 6(Suppl 1):S1 S5

Brehm V (1937) Ssswasserorganismen aus dem Elbursgebirge (Persien). Zool Anz 118:214 223

Dimentman C, Por FD (1985) Diaptomidae (Copepoda, Calanoida) of Israel and Northern Sinai. Hydrobiologia 127:89 95

Dumont HJ (1979) Limnologie van Sahara en Sahel. Thesis. Rijksuniversiteit Gent

Dumont HJ (2009) The crustacean zooplankton (Copepoda, Branchiopoda), Atyid Decapoda, and Syncarida of the Nile basin. In: Dumont HJ (ed) The Nile: Origin, Environments, Limnology and Human Use, Monographiae Biologicae 89. Springer, The Netherlands, pp 521545

Dussart B (1989) Crustacs Coppodes Calanoides des eaux intrieures africaines. Crustaceana 15(Suppl):1 2015

Dussart B, Defaye D (2001) Introduction to Copepods, 2nd edn. Backhuys Publishers, Leiden

Dussart B, Defaye D (2002) World directory of Crustacea Copepoda of inland waters. Backhuys Publishers, Leiden, I Calaniformes

Fadda A, Markov S, Kotlk P, Lugli A, Padedda B, Buscarinu P, Sechi N, Manca M (2011) First record of planktonic crustaceans in Sardinian reservoirs. Biologia 66:856 865

Ferrari I, Farabegoli A, Pugnetti A, Stella E (1991) The occurrence of a Calanoid Australasian species, Boeckella triarticulata (Thomson), in fish ponds of Northern Italy. Verh Int Verein Limnol 24:2822 2827

Fischer O (1953) Notes on the zooplankton of Israel fish ponds. Bull Res Counc Israel 2:441 442

Gophen M (1979) Extinction of Daphnia lumholtzi (Sars) in Lake Kinneret (Israel). Aquaculture 16:67 71

Gndz E (1998) Eudiaptomus anatolicus n.sp. (Copepoda: Calanoida) from Turkey. Hydrobiologia 368:193 199

Guindon S, Gascuel O (2003) A simple, fast, and accurate algorithm to estimate large phylogenies by maximum likelihood. Syst Biol 52:696 704

Gurney R (1921) Freshwater Crustacea collected by Dr. P. A. Buxton in Mesopotamia and Persia. J Bombay Nat Hist Soc 27:835 843
Hall TA (1999) BioEdit: a user-friendly biological sequence alignment editor and analysis program for Windows 95/98/NT. Nucleic Acids Symp Ser 41:95 98

Jaume D (1989) Metadiaptomus chevreuxi (Copepoda: Calanoida: Diaptomidae) and Leptestheria mayeti (Branchiopoda: Conchostraca: Leptestheriidae), two African freshwater crustaceans recorded in Majorca. Limnetica 5:101 109

Khalaf TA (2008) A new species of Phyllodiaptomus Kiefer (Copepoda, Calanoida) from the Shatt Al-Arab river, southern Iraq. Crustaceana 81:257 269

Kiefer F (1930) Zur Kenntnis der Copepodenfauna Palstinas. Zool Anz 92:242 246

Kiefer F (1932) Versuch eines Systems der Diaptomiden (Copepoda Calanoida). Zool Jb Syst 63:451 520

Kiefer F (1974) Zur Kenntnis von Morphologie und Systematik einiger Arten der Gattung Arctodiaptomus Kiefer (Crustacea, Copepoda). Zool Scripta 3:11 22

Kiefer F (1978a) Das Zooplankton der Binnengewsser. Freilebende Copepoda. Die Binnengewsser 26:1 343, E. Schweizerbart'sche Verlagsbuchhandlung, Stuttgart

Kiefer F (1978b) Zur Kenntnis der Copepodenfauna gyptischer Binnengewsser. Arch Hydrobiol 84:480 499

Leibold MA, Economo EP, Peres-Neto P (2010) Metacommunity phylogenetics: separating the roles of environmental filters and historical biogeography. Ecol Lett 13:1290 1299

Lffler H (1956) Limnologische Beobachtungen an Iranischen Binnengewssern. Hydrobiologia 8:239 278

Lffler H (1961) Beitrge zur Kenntnis der Iranischen Binnengewsser II: regional-limnologische Studie mit besonderer Bercksichtigung der Crustaceenfauna. Int Revue Ges Hydrobiol 46:309 406

Marrone F (2006) The microcrustacean fauna of Sicily and the Central Mediterranean Sea area current knowledge and gaps to be filled. Pol J Ecol 54:681 685

Marrone F, Naselli-Flores $L$ (2005) First record of a representative of the subfamily Paradiaptominae (Copepoda Calanoida Diaptomidae) in Italy: Metadiaptomus chevreuxi (Guerne \& Richard, 1894). J Limnol 64:89 92

Marrone F, Castelli G, Barone R, Naselli-Flores L (2005) Ecology and distribution of calanoid copepods in Sicilian inland waters (Italy). Verh Internat Verein Limnol 29:2150 2156

Marrone F, Lo Brutto S, Arculeo M (2010) Molecular evidence for the presence of cryptic evolutionary lineages in the freshwater copepod genus Hemidiaptomus G.O. Sars, 1903 (Calanoida, Diaptomidae). Hydrobiologia 644:115 125

Marrone F, Lo Brutto S, Hundsdoerfer AK, Arculeo M (2013) Overlooked cryptic endemism in copepods: systematics and natural history of the calanoid subgenus Occidodiaptomus Borutzky 1991 (Copepoda, Calanoida, Diaptomidae). Mol Phylogenet Evol 66:190 202

Mohamed HH, Salman SD (2009) Copepoda of the Southern Iragi Marshes. 1. Calanoida. Marsh Bull 4:148 161

Nylander JAA (2004) Program Distributed by the Author. Evolutionary Biology Centre, Uppsala University

Petkovski TK (1961) ber einige Diaptomiden aus Jugoslawien und Israel (Crustacea: Copepoda Calanoida). Acta Mus maced Sci nat Skopje 7:175 201

Petkovski TK (1983) Calanoides - Calanoida (Crustacea -Copepoda). Faune de Macdoine. Muse Histoire Naturelle de Macedonie, Skopje, p 5

Por FD (1984) An outline of the distribution patterns of freshwater Copepoda of Israel and surroundings. Hydrobiologia 113:151 154

Ranga-Reddy Y (1994) Copepoda: Calanoida: Diaptomidae. Key to the genera Heliodiaptomus, Allodiaptomus, Neodiaptomus, Phyllodiaptomus, Eodiaptomus, Arctodiaptomus and Sinodiaptomus. Guides to the Identification of the Microinvertebrates of the Continental Waters of the World. SPB Academic Publishing, The Hague, p 5

Rayner NA (1999) Copepoda: Calanoida (Diaptomidae: Paradiaptominae). Guides to the identification of the Microinvertebrates of the Continental Waters of the World. Backhuys Publishers, Leiden

Richard J (1893) Coppodes recueillis par M. le Dr. Th. Barrois en Egypte, en Syrie et en Palestine. Revue Biologique du Nord de la France 5:3 36

Ronquist F, Teslenko MP, van der Mark DL, Ayres A, Darling S, Hhna B, Larget L, Suchard MA, Huelsenbeck JP (2012) MrBayes 3.2: efficient Bayesian phylogenetic inference and model choice across a large model space. Syst Biol 61:539 542

Rossetti G, Dussart B, Viaroli P (1996) Finding of the calanoid Eudiaptomus gracilis (Sars) in perifluvial environments of the Po River. Mem Ist ital Idrobiol 54:51 59

Ruffo S, Stoch F (2005) Checklist e distribuzione della fauna italiana. 10.000 specie terrestri e delle acque interne. Mem Mus Civ St Nat Verona, Sez Scienze della Vita 16:1 307 
Samchyshyna L (2011) Faunistical overview of calanoid copepods (Crustacea) from continental waters of Ukraine. Vestn zool 45:299 305

Sanoamuang L, Teeramaethee J (2006) Phyllodiaptomus thailandicus, a new freshwater copepod (Copepoda, Calanoida, Diaptomidae) from Thailand. Crustaceana 79:475 487

Spandl H (1923) Zur Kenntnis der Susswasser-Mikrofauna Vorderasiens. Ann Naturhist Mus Wien 36:124 149

Staton JL, Taylor BE, Schizas NV, Wetzer R, Glenn TC, Coull BC (2003) Mitochondrial gene diversity of Skistodiaptomus mississippiensis in impoundments of the Upper Coastal Plain near Aiken, South Carolina, USA. Arch Hydrobiol 158:215 231

Stella E (1970) Diaptomidi della Sardegna. Ist Lomb (Rend Sc) B 104:69 87

Stella E (1984) Copepoda: Calanoida. XXI Fauna d'Italia, Calderini, Bologna

Stella E, Margaritora FG, Cottarelli V (1972) La fauna ad entomostraci di acque astatiche della Sardegna nord orientale. Ricerche biologiche ed ecologiche. Rendiconti Accademia Nazionale dei XL 4:3 50

Stella E, Margaritora G (1975/1976) Contributo alla conoscenza della fauna ad entomostraci di acque astatiche della Sardegna (zone Nord occidentale e Centrale). Considerazioni ecologiche e biogeografiche. Rendiconti Accademia Nazionale dei XL 5:1 11

Swofford DL (1998) PAUP*. Phylogenetic analysis using parsimony (*and other methods). Version 4. Sinauer Associates, Sunderland, Massachusetts

Tamura K, Peterson D, Peterson N, Stecher G, Nei M, Kumar S (2011) MEGA5: molecular evolutionary genetics analysis using maximum likelihood, evolutionary distance, and maximum parsimony methods. Mol Biol Evol 28:2731 2739

Thum R, Derry AM (2008) Taxonomic implications for diaptomid copepods based on contrasting patterns of mitochondrial DNA sequences in four morphospecies. Hydrobiologia 614:197 207

Thum RA, Harrison RG (2009) Deep genetic divergences among morphologically similar and parapatric Skistodiaptomus (Copepoda: Calanoida: Diaptomidae) challenge the hypothesis of Pleistocene speciation. Biol J Linn Soc 96:150 165

Turki S, Turki B (2010) Copepoda and Branchiopoda from Tunisian temporary waters. Int J Biodivers Conserv 2:86 97

Ustaoğlu MR (2004) A check-list for zooplankton of Turkish inland waters. E.U. J Fisheries Aquat Sci 21:191 199

Ustaoğlu MR, Balik S, Mis DO, Aygem C (2005) The zooplankton of some mountain lakes in the Taurus Range (Turkey). Zool Middle East 34:101 108

Yaron Z (1964) Notes on the ecology and entomostracan fauna of temporary rainpools of in Israel. Hydrobiologia 24:489 513

doi:10.1186/s40555-014-0074-7

Cite this article as: Marrone et al: The diaptomid fauna of Israel

(Copepoda, Calanoida, Diaptomidae), with notes on the systematics of Arctodiaptomus similis (Baird, 1859) and Arctodiaptomus irregularis Dimentman \& Por, 1985 stat. rev. Zoological Studies 2014 53:74.

\section{Submit your manuscript to a SpringerOpen ${ }^{\circ}$ journal and bene冈t from:}

- Convenient online submission

- Rigorous peer review

- Immediate publication on acceptance

- Open access: articles freely available online

- High visibility within the 囚eld

- Retaining the copyright to your article

Submit your next manuscript at $\gg$ springeropen.com 